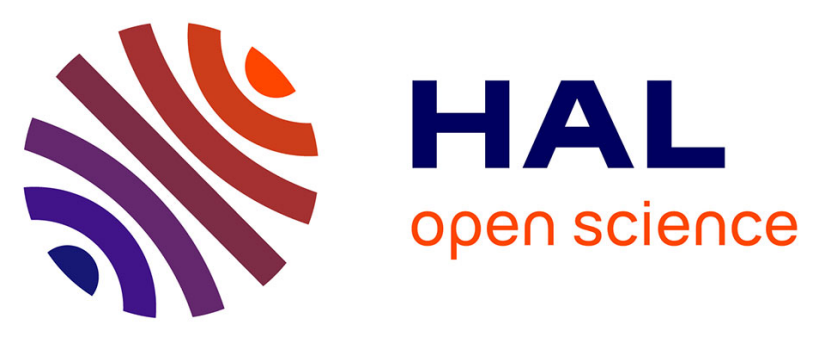

\title{
Production of hydrogen sulfide by the intestinal microbiota and epithelial cells and consequences for the colonic and rectal mucosa
}

Francois Blachier, Mireille Andriamihaja, Pierre Larraufie, Eunyeong Ahn, Annaig Lan, Eunjung Kim

\section{To cite this version:}

Francois Blachier, Mireille Andriamihaja, Pierre Larraufie, Eunyeong Ahn, Annaig Lan, et al.. Production of hydrogen sulfide by the intestinal microbiota and epithelial cells and consequences for the colonic and rectal mucosa. AJP - Gastrointestinal and Liver Physiology, 2021, 320 (2), pp.G125-G135. 10.1152/ajpgi.00261.2020 . hal-03033013

HAL Id: hal-03033013

https://hal-agroparistech.archives-ouvertes.fr/hal-03033013

Submitted on 7 Dec 2020

HAL is a multi-disciplinary open access archive for the deposit and dissemination of scientific research documents, whether they are published or not. The documents may come from teaching and research institutions in France or abroad, or from public or private research centers.
L'archive ouverte pluridisciplinaire HAL, est destinée au dépôt et à la diffusion de documents scientifiques de niveau recherche, publiés ou non, émanant des établissements d'enseignement et de recherche français ou étrangers, des laboratoires publics ou privés. 
1 Production of hydrogen sulfide by the intestinal microbiota and epithelial

2 cells and consequences for the colonic and rectal mucosa

3 François Blachier ${ }^{1}$, Mireille Andriamihaja ${ }^{1}$, Pierre Larraufie ${ }^{1}$, Eunyeong Ahn ${ }^{2}$,

4 Annaïg Lan ${ }^{1}$, Eunjung Kim ${ }^{2}$

$5 \quad{ }^{1}$ UMR PNCA, Nutrition Physiology and Alimentary Behavior, Université Paris-

6 Saclay, AgroParisTech, INRAE, Paris, France

7 '2Department of Food Science and Nutrition, Daegu Catholic University,

8 Gyeongsan, South Korea

9

Abbreviated title: Hydrogen sulfide and large intestine

11 Corresponding author: François Blachier, francois.blachier@agroparistech.fr,

12 UMR914 Nutrition Physiology and Ingestive Behavior, 16 rue Claude Bernard, 1375005 Paris, France. 
Abstract

Among bacterial metabolites, hydrogen sulfide $\left(\mathrm{H}_{2} \mathrm{~S}\right)$ has received increasing attention. The epithelial cells of the large intestine are exposed to two sources of $\mathrm{H}_{2} \mathrm{~S}$. The main one is the luminal source that results from specific bacteria metabolic activity towards sulfur-containing substrates. The other source in colonocytes is from the intracellular production mainly through cystathionine beta-synthase (CBS) activity. $\mathrm{H}_{2} \mathrm{~S}$ is oxidized by the mitochondrial sulfide oxidation unit, resulting in ATP synthesis, and thus establishing this compound as the first mineral energy substrate in colonocytes. However, when the intracellular $\mathrm{H}_{2} \mathrm{~S}$ concentration exceeds the colonocyte capacity for its oxidation, it inhibits the mitochondrial respiratory chain, thus affecting energy metabolism. Higher luminal $\mathrm{H}_{2} \mathrm{~S}$ concentration affects the integrity of the mucus layer and displays pro-inflammatory effects. However, a low/minimal amount of endogenous $\mathrm{H}_{2} \mathrm{~S}$ exerts an anti-inflammatory effect on the colon mucosa pointing out the ambivalent effect of $\mathrm{H}_{2} \mathrm{~S}$ depending on its intracellular concentration. Regarding colorectal carcinogenesis, forced CBS expression in late adenoma-like colonocytes increased their proliferative activity, bioenergetics capacity, and tumorigenicity; while genetic ablation of CBS in mice resulted in a reduced number of mutagen-induced aberrant crypt foci. Activation of endogenous $\mathrm{H}_{2} \mathrm{~S}$ production and low $\mathrm{H}_{2} \mathrm{~S}$ extracellular concentration enhance cancerous colorectal cells proliferation. Higher exogenous $\mathrm{H}_{2} \mathrm{~S}$ concentrations markedly reduce mitochondrial ATP synthesis and proliferative capacity in cancerous cells, enhance glycolysis, but do not affect their ATP cell content nor viability. Thus, it appears that, notably through an effect on colonocyte energy metabolism, endogenous and microbiotaderived $\mathrm{H}_{2} \mathrm{~S}$ are involved in the host intestinal physiology and physiopathology.

Key words: hydrogen sulfide, energy metabolism, inflammatory bowel diseases, colorectal carcinogenesis 


\section{Introduction}

The intestinal microbiota in different physiological and pathophysiological situations is characterized by its composition, diversity, and metabolic capacities (93). Regarding the catabolic side of the metabolic activities, the microbial species can produce a variety of compounds by degrading undigested (or not fully digested) alimentary and endogenous substrates (11). Among the substrates used by bacteria for catabolism, the undigested dietary and endogenous proteins are degraded through the protease and peptidase activities releasing amino acids (75). The amino acids are not absorbed to any significant extent by the colonic epithelium except in the neonatal period (90). They can then be used by the intestinal bacteria for their own protein synthesis, and in other various metabolic pathways leading to the production of numerous metabolic end products that are released in the large intestine luminal content (23).

Among these bacterial metabolites, $\mathrm{H}_{2} \mathrm{~S}$ has received increasing attention in the last decades as a compound that was initially considered as a toxic substance when present in excess in the environment (73), while acting as a gaseous mediator involved in numerous physiological functions when synthesized endogenously (37). The aim of this review is to present an overview of the experimental and clinical evidence that allow to consider $\mathrm{H}_{2} \mathrm{~S}$ as an important player in the communication between some bacterial species in the intestinal microbiota and the large intestine epithelial cells in different physiological and pathophysiological situations.

\section{Production of luminal $\mathrm{H}_{2} \mathrm{~S}$ by the intestinal bacteria}

$\mathrm{H}_{2} \mathrm{~S}$ is produced by different bacterial species from both dietary and endogenous compounds of organic and inorganic nature (13) (Figure 1). Recent data suggest that $\mathrm{H}_{2} \mathrm{~S}$ is mainly produced through cysteine catabolism, and to a lower extent by sulfate reducing bacteria (SRB) (36). Cysteine catabolic bacteria include Fusobacterium, Clostridium, Escherichia, Salmonella, Klebsiella, Streptococcus, Desulfovibrio, and Enterobacter which convert cysteine to $\mathrm{H}_{2} \mathrm{~S}$, pyruvate, and ammonia by the enzymatic activity of cysteine desulfhydrase (8). SRB includes Desulfovibrio, Desulfobacter, Desulfobulbus, and Desulfotomaculum. Desulfovibrio is the dominant genera of SRB, and it includes D.piger and D.desulfuricans (72). The numerous microbes belonging to SRB possess the capacity to reduce several compounds including sulfate, sulfite, thiosulfate, elemental sulfur, and several thionates (13). The capacity of some 
bacteria to cope with surrounding $\mathrm{H}_{2} \mathrm{~S}$ may be related to some specific metabolic characteristics. For instance in Escherichia Coli, cytochrome bd-type $\mathrm{O}_{2}$-oxidases that are relatively insensitive to sulfide allow bacterial oxygen consumption and growth in the presence of this compound (30).

The concentrations of sulfide measured in the colon luminal content and in the feces are rather variable depending on the processing of the biological materials and on the technique used for the assay. Some techniques are specific for sulfide detection, like for instance the targeted GC-MS measurement (41); while others are rather unspecific and detect other sulfurcontaining compounds. Thus, concentrations of sulfide measured in the large intestine content and in faecal material (that latter representing an approximation of the concentration in the rectum) in mammals ranges from 0.2 $\mathrm{mM}$ up to $2.0 \mathrm{mM}$ (13). This order of magnitude difference, apart from the specificity of the techniques used for measurement, may also be explained by the fact that the luminal concentration of sulfide in the large intestine is dependent on the dietary status of the individuals. For instance, the consumption of a diet with a high protein content, where some dietary and endogenous proteins escape digestion in the small intestine (26) results in an increased amount of sulfide in the colon luminal content, and in the fecal material, when compared with the situation of lower protein intake $(9,59)$. Sulfide in the luminal content can exist in 3 forms: the $\mathrm{H}_{2} \mathrm{~S}$ gas that is partly dissolved in the aqueous phase, and is highly diffusible, hydrosulfide anion HS, and sulfide ion $\mathrm{S}^{2-}$, this latter being present at a negligible level. Indeed, in aqueous phase, $\mathrm{H}_{2} \mathrm{~S}$ dissociate in $\mathrm{HS}^{-}$and $\mathrm{S}^{2-}$ and $\mathrm{H}^{+}$with pKa values being 7.04 and 11.96 respectively (13). In healthy subjects, the $\mathrm{pH}$ at the colonic mucosal surface ranges between 7.2 and 7.5 in the descending colon and rectum (14). Thus, considering a $\mathrm{pH}$ of 7.4, approximately one third of sulfide is in the form of $\mathrm{H}_{2} \mathrm{~S}$ at equilibrium with two third being hydrosulfide anion. However, when the luminal $\mathrm{pH}$ is more acidic, the $\mathrm{H}_{2} \mathrm{~S} / \mathrm{HS}^{-}$ratio in the large intestine increases. Taking into account that $\mathrm{H}_{2} \mathrm{~S}$, unlike $\mathrm{HS}^{-}$easily penetrates biological membranes (14), lower $\mathrm{pH}$ will increase $\mathrm{H}_{2} \mathrm{~S}$ concentration, then amplifying its entry in the colonic epithelial cells. Lastly, measurement in human faeces showed that $8 \%$ of sulfide are in unbound form (45), representing a concentration around 60 $\mu \mathrm{M}$, while measurement in the rat caecal content suggests that $0.2 \%$ of total luminal sulfide is in unbound form (55). Several compounds from dietary origin that are not fully absorbed by the small intestine have been shown to bind $\mathrm{H}_{2} \mathrm{~S}$. These compounds include zinc (83), heme (43), and polyphenols (1). 
Incidentally, by comparing both free $\mathrm{H}_{2} \mathrm{~S}$ and bound sulfane sulfur concentrations in blood plasma recovered from conventional and germ-free rodents, it was found that these concentrations are markedly lower in animals with no intestinal microbiota, thus suggesting that the circulating $\mathrm{H}_{2} \mathrm{~S}$ is largely originating from the microbiota metabolic activity (79). This result is in accordance with the fact that fecal $\mathrm{H}_{2} \mathrm{~S}$ synthesis in germ-free mice represents approximately half of that observed in colonized mice (28).

\section{$\mathrm{H}_{2} \mathrm{~S}$ and the absorbing colonic epithelial cells}

The colonic epithelium is a monolayer of cells that make the border between the outer and the inner media. This epithelium is structurally organized as colonic crypts and surface epithelium. This structure that is continuously renewed within few days, contains stem cells located at the crypt bottom, and differentiated cells with specialized functions including absorbing colonocytes, enteroendocrine cells, goblet cells, and Tuft cells $(64,89)$. These different cell phenotypes are polarized with a luminal side being protected by mucous layers that face the luminal content (44), and a baso-lateral side in close contact with the basal lamina, lamina propria and the capillaries (95). The fully mature colonocytes are finally exfoliated into the luminal content mainly by apoptosis (78). The renewal of the colonic epithelium is depending on a coordinated sequence of events that allow to maintain the epithelium homeostasis (24).

The absorbing colon epithelial cells, often referred as colonocytes, are responsible for water absorption, and electrolyte absorption and secretion (6). These cells are characterized by relatively high energy requirement due to intense anabolism and the catalytic activity of the $\mathrm{Na} / \mathrm{K}$ ATPase involved in sodium absorption (12). The colonocytes are equipped with the so-called sulfide-oxidizing unit (SOU), a mitochondrial multi-enzymatic system responsible for the oxidation of $\mathrm{H}_{2} \mathrm{~S}$ (Figure 2). When the extracellular concentration of NaHS, a rapid $\mathrm{H}_{2} \mathrm{~S}$ donor, is below a threshold value, approximately equal to $50 \mu \mathrm{M}$, the colonocytes are able to oxidize sulfide to thiosulfate in three steps (33) allowing the production of ATP (16). The first enzyme of the SOU is sulfide quinone reductase (SQR) that injects electrons into the mitochondrial respiratory chain through quinone before transfer to complex III cytochrome c, and finally reduction of oxygen to water at the level of complex IV (cytochrome oxidase). The persulfide formed in the first step of SOU activity is oxidized by the sulfur dioxygenase ETHE1 to sulfite. Disruption of the mitochondrial ETHE1 in mice is lethal 5 weeks after birth, indicating sulfide 
172 toxicity, and vital importance of ETHE1 for sulfide disposal (85). Finally, the 173 sulfur transferase rhodanese converts sulfite into the metabolic end product thiosulfate (Figure 2) (56). Sulfide oxidation pathway is mainly localized apically in human colonic crypts (58). When the expression of the genes coding for the 3 enzymes of the SOU was measured in human biopsies recovered from different anatomical parts of the large intestine, the rhodanese was found to be much less expressed in the rectum than in more proximal parts (that are caecum, ascending, transverse and descending colon), suggesting a lower capacity for sulfide disposal in the rectum (60).

Thus, $\mathrm{H}_{2} \mathrm{~S}$ can be considered as an inorganic fuel for colonocytes in addition to the usual main organic energy substrates provided through the luminal and baso-lateral sides, and used by colonocytes (e.g. short-chain fatty acids at the luminal side, and glutamine, and glucose at the baso-lateral side). $\mathrm{H}_{2} \mathrm{~S}$ in fact represents the first inorganic energy substrate for mammalian cells (34). However, in in vitro studies, when the extracellular concentration of NaHS is above $50 \mu \mathrm{M}$, an inhibition of the colonocyte respiration is observed (9). This is due to an inhibition of the catalytic activity of the cytochrome c oxidase, one of the complex in the mitochondrial respiratory chain (complex IV) (65) (Figure 2). In addition, in isolated human colonocytes, $\mathrm{H}_{2} \mathrm{~S}$ inhibits butyrate oxidation (5). Thus overall, the capacity of colonocytes to oxidize limited amount of sulfide in mitochondria appears to represent a way to detoxify this compound while recovering energy from it. Such a capacity can be altered by other gaseous mediator like nitric oxide (NO). Indeed, the NO donor MAMA NONOate, which markedly inhibits oxygen consumption in rat colonocytes by inhibiting mitochondrial cytochrome coxidase activity $(9,22)$, prevents $\mathrm{H}_{2} \mathrm{~S}$ detoxification in colonocytes.

Several processes have been described regarding the adaptive capacity of colonocytes to face an increased concentration of $\mathrm{H}_{2} \mathrm{~S}$ in the extracellular medium. By feeding rodents with high-protein diet, and thus by increasing the cysteine availability for $\mathrm{H}_{2} \mathrm{~S}$ production by the large intestine microbiota, an increased content of $\mathrm{H}_{2} \mathrm{~S}$ was recorded as expected in the caecal and colonic luminal fluids, and this increased concentration coincided with an increased expression in colonocytes of the Sqr gene that is coding for SQR, the first enzyme in SOU (9).

However, it is worth noting that colonocytes are not only exposed to $\mathrm{H}_{2} \mathrm{~S}$ from their luminal side, but can also synthesize this mediator intracellularly from 
cysteine and other co-substrates. The major pathway in colonocytes, appears to be through the activity of cystathionine beta-synthase (CBS), a versatile enzyme that is able to convert cysteine to $\mathrm{H}_{2} \mathrm{~S}$ and serine, but also 2 molecules of cysteine into $\mathrm{H}_{2} \mathrm{~S}$ and lanthionine, and cysteine and homocysteine into $\mathrm{H}_{2} \mathrm{~S}$ and cystathionine (36). NO has been shown to interfere with $\mathrm{H}_{2} \mathrm{~S}$ endogenous synthesis through the binding to CBS heme, a process that results in inhibition of CBS catalytic activity $(33,91)$. This indicates that the cellular metabolism of $\mathrm{H}_{2} \mathrm{~S}$ may depend on the local concentration of NO.

Thus, the intracellular $\mathrm{H}_{2} \mathrm{~S}$ concentration in colonocytes depends on the diffusion of luminal $\mathrm{H}_{2} \mathrm{~S}$ through the brush-border membrane, on the intracellular synthesis from cysteine, and on the capacity of colonocytes for its oxidation.

\section{$\mathrm{H}_{2} \mathrm{~S}$ and the enteroendocrine cells}

Among intestinal epithelial cells, enteroendocrine cells (EECs) secrete gut hormones that regulate many functions in the host, including food intake, insulin secretion or intestinal motility and epithelial barrier (35). EECs express a high number of receptors and channels that enable them to secrete hormones in response to different stimuli. Secretion is highly stimulated in the small intestine by nutrients arriving in the lumen of the gut after food intake, but many other compounds, including the ones present in the bloodstream, have been shown to stimulate gut hormone release. Moreover, different EEC subtypes differ by their hormonal production, but also according to the receptors they express, enabling a fine control of the different hormone secretion (10). EECs in the colon have also been shown to be involved in the regulation of metabolic functions despite not being directly stimulated by nutrients $(57,82)$, but rather by microbial derived compounds $(3,52,86)$.

However, little is known on the impact of $\mathrm{H}_{2} \mathrm{~S}$ on EEC physiology or secretion in the large intestine. In GluTag cells, a murine colonic L-cell model, Pichette and collaborators have showed that slow- and rapid-releasing sulfide donors dosedependently increased GLP-1 secretion, with an effect dependent on p38 MAPK signalling (70). Interestingly, in this study, the authors by using the prebiotic chondroitin sulfate, that increases the abundance of the SRB D-piger and sulfate moiety in the distal intestine, measured an increased $\mathrm{H}_{2} \mathrm{~S}$ production. Such increased production was associated with metabolic improvements through increased GLP-1 secretion during oral glucose tolerance tests. 
Using cells originating from a more proximal region of the gastrointestinal tract, Slade and collaborators showed that the slow-releasing sulfide donor GYY4137 dose-dependently reduced the secretion of ghrelin in rat gastric primary culture. Ghrelin represents the main gut orexigenic hormone that regulates adiposity and gastrointestinal motility. Its secretion pattern is opposite to most gut hormones, as its secretion is inhibited by food intake. As ghrelin producing cells are present in the stomach, it is likely that the main source of $\mathrm{H}_{2} \mathrm{~S}$ there is through endogenous production. In fact, these cells express high level of cystathionine-gamma lyase (CSE), one of the enzymes involved in $\mathrm{H}_{2} \mathrm{~S}$ endogenous production (81). Inhibition of endogenous $\mathrm{H}_{2} \mathrm{~S}$ production increased ghrelin secretion. Similar inhibitory effects of $\mathrm{H}_{2} \mathrm{~S}$ on EEC secretion has been described by Bala and collaborators (7). Sulfide donors at high concentration strongly inhibited glucagon-like peptide 1 (GLP-1) and peptide-YY (PYY) secretion induced by Takeda-G-protein-receptor-5 (TGR5) stimulation in STC-1 cells, a cellular EEC model of murine small intestine that are poorly differentiated (7). Interestingly, L-cysteine, which increases $\mathrm{H}_{2} \mathrm{~S}$ endogenous production, also inhibited GLP-1 and PYY stimulated secretion.

\section{$\mathrm{H}_{2} \mathrm{~S}$ and colonic inflammation}

Chronic inflammatory bowel diseases (IBD), mainly Crohn's disease and ulcerative colitis (UC) are characterized by alternating episodes of remission and relapse, resulting from inappropriate mucosal immune responses against luminal intestinal components in genetically predisposed individuals (48). Although Crohn's disease and UC have different clinical features (67), the inflammation of the intestinal mucosa is often observed in the distal parts of the intestine (32). Etiology of IBD, although still largely elusive, is related to genetic (50), and environmental factors including the ones from dietary origin (92). The concept that excessive concentration of $\mathrm{H}_{2} \mathrm{~S}$ in the intestinal luminal content, notably in a context of diminished capacity for sulfide disposal in the mucosa (2), may participate in the etiology of mucosal inflammation has been proposed more than 2 decades ago (54). Severity of mucosal inflammation in the colon and rectum of patients with active UC is believed to be related to the concentration ratio of deleterious vs. beneficial bacterial metabolites. This ratio is notably depending on the substrate availability for production of these metabolites. Following for one year UC patients in remission, it was found that patients with high consumption of meat, dietary protein and sulfur/sulfate experienced an increased rate of relapse when compared with patients with low consumption of these compounds (46). This indicates that increased intake 
of dietary substrates known to be used by the intestinal microbiota for $\mathrm{H}_{2} \mathrm{~S}$ synthesis, is associated with increased risk of relapse. In anesthesized rats, after preliminary evacuation of the luminal content, intracolonic instillation of NaHS used for 1 hour at concentrations between 0.5 and $1.5 \mathrm{mM}$, increased in colonocytes the expression of inflammation-related genes, namely those coding for the inducible form of nitric oxide synthase (iNOS), and interleukin-6 (9). Overexpression of iNOS is measured in colonic samples originating from patients with UC (80), and NO production in excess, notably through increased peroxynitrite formation, appears to play a role in the process of mucosal inflammation.

ljssennagger and collaborators have shown that microbiota-derived $\mathrm{H}_{2} \mathrm{~S}$ at high concentration destabilizes the protective mucus layer covering the intestinal epithelium through the reduction of disulfide bonds linking the mucin 2 network (42) (Figure 3), a process that would increase the interactions between bacteria and the epithelium. Mottawea and coworkers have studied the microbiota composition of new-onset pediatric Crohn's disease patients, and found that this microbiota is characterized by high abundance of Atopobium, Fusobacterium, Veillonella, Prevotella, Streptococcus, and Leptotrichia, several members of those genera being known to produce $\mathrm{H}_{2} \mathrm{~S}$ through the catabolism of sulfur-containing amino acids (63). Importantly, in this cohort, the abundance of $\mathrm{H}_{2} \mathrm{~S}$ producers from cysteine was correlated with the severity of mucosal inflammation. To document the possible causal link between $\mathrm{H}_{2} \mathrm{~S}$ production and intestinal inflammation, the authors colonized Interleukin-10 mice with the $\mathrm{H}_{2} \mathrm{~S}$ producer Atopobium parvulum and measured a worsening of colitis, such a deleterious effect being attenuated by the $\mathrm{H}_{2} \mathrm{~S}$ scavenger bismuth. In addition, in the same Crohn's disease pediatric cohort, the colonic mucosa biopsies displayed decreased expression of the mitochondrial enzymes involved in $\mathrm{H}_{2} \mathrm{~S}$ detoxification. Overall, the results from this study strongly suggest that diminished capacity for sulfide disposal in the colonic mucosa of pediatric Crohn's disease patients amplify the pro-inflammatory effect of $\mathrm{H}_{2} \mathrm{~S}$ overproduction by the intestinal microbiota (Figure 3).

Thus, evidence from both experimental and clinical studies have highlighted that high $\mathrm{H}_{2} \mathrm{~S}$ concentrations, i.e. above the capacity of the intestinal mucosa to detoxify this bacterial metabolite, increase the risk of inflammation. However, it appears from experimental studies using pharmacological inhibitors of $\mathrm{H}_{2} \mathrm{~S}$ synthesis or $\mathrm{H}_{2} \mathrm{~S}$-releasing compounds, that a minimal amount of sulfide is likely necessary to limit the risk of colonic mucosal inflammation. Then, the concept 
that $\mathrm{H}_{2} \mathrm{~S}$ is a double-edge sword for the intestinal epithelium has been proposed (15). Indeed, several in vivo studies found that inhibition of $\mathrm{H}_{2} \mathrm{~S}$ endogenous synthesis favors intestinal inflammation and delays colitis resolution $(40,94)$. The capacity for $\mathrm{H}_{2} \mathrm{~S}$ production was markedly elevated after colitis induction in rat, and inhibition of $\mathrm{H}_{2} \mathrm{~S}$ synthesis in colon exacerbated the colitis. Interestingly, $\mathrm{H}_{2} \mathrm{~S}$ has been shown to exert some antioxidant activity, notably by persulfidation of cysteine residues that protects these residues from oxidative damage (33). This action may contribute to the anti-inflammatory effect of low production of $\mathrm{H}_{2} \mathrm{~S}$ in colonocytes. Regarding colitis resolution, $\mathrm{H}_{2} \mathrm{~S}$-releasing compounds have been shown to promote this process through Hypoxia-Inducible factor-1alpha signaling pathway (29) Endogenous synthesis of $\mathrm{H}_{2} \mathrm{~S}$ was found to offer some protection against dextran sodium sulfate (DSS)-induced colitis in rodents partly by inhibiting the activation of NLRP3 inflammasome pathway (71). Also, the slow-releasing sulfide donor GYY4137 was shown to reduce in vitro the lipopolysaccharide or TNF-alpha/IFN-gamma induced increased permeability in colonocyte monolayer (21), and the intraperitoneal injection of GYY4137 in endotoxemic animals protects against intestinal barrier dysfunction in vivo (100). In addition, this $\mathrm{H}_{2} \mathrm{~S}$ donor improves mesenteric perfusion and intestinal injury in an experimental model of necrotizing enterocolitis, and these beneficial effects appear to be mediated through constitutive endothelial nitric oxide synthase (e-NOS)-dependent pathways (25). Lastly, endogenous production of $\mathrm{H}_{2} \mathrm{~S}$ appears to contribute to mucus production thus favoring segregation between luminal bacteria and the intestinal mucosa (62). From the different available results, it appears that the effects of the diffusible compound $\mathrm{H}_{2} \mathrm{~S}$ on the inflammatory process in the intestinal mucosa depend both on the exogenous production by the microbiota, and on the endogenous production by the host colonic tissue.

\section{$\mathrm{H}_{2} \mathrm{~S}$ and colon carcinogenesis}

Some recent experimental and clinical studies suggest that both endogenous synthesis of $\mathrm{H}_{2} \mathrm{~S}$ in colonic epithelial cells and luminal exogenous $\mathrm{H}_{2} \mathrm{~S}$ are implicated in the process of colorectal carcinogenesis. Gene and protein expression has revealed that the $\mathrm{H}_{2} \mathrm{~S}$-synthesizing enzyme CBS is increased in colonic tumors when compared with the surrounding mucosa $(66,84)$, suggesting an increased capacity for $\mathrm{H}_{2} \mathrm{~S}$ synthesis in the cancerous samples. However, since colonic tumors and surrounding tissues contained numerous 
this enzyme in colonic epithelial cells and other cell types. Upregulation of CBS in human biopsies of precancerous adenomatous polyps has been measured, and forced upregulation of CBS in late adenoma-like colonic epithelial cells was associated with differences in the expression of genes involved in colorectal cancer development, notably genes involved in NFkappa B, KRAS, and p53 signaling (69). Also these cells overexpressing CBS were characterized by increased proliferative capacity, and enhanced cellular bioenergetics capacity in terms of respiration and glycolysis. This increased CBS expression reinforced cell tumorigenicity in athymic nude mice. Of equal importance, genetic ablation of CBS in mice resulted in a reduction of the number of mutagen-induced aberrant crypt foci (69). Thus, increased endogenous production of $\mathrm{H}_{2} \mathrm{~S}$ within adenomatous colonocytes increases their proliferative capacity (Figure 4) and their ability to promote tumor formation.

Increased supply of $\mathrm{H}_{2} \mathrm{~S}$ produced by the intestinal microbiota has been implicated in the process of colorectal carcinogenesis. Indeed, by collecting feces and tissues samples collected on and off the tumor site in the same individuals, and by using multiomic data and community metabolic models to assess $\mathrm{H}_{2} \mathrm{~S}$ production in colorectal cancer, Hale et al. obtained data indicating an increased $\mathrm{H}_{2} \mathrm{~S}$ production by the gut bacteria in colonic cancer samples compared to non- cancerous samples (38). The predicted increased $\mathrm{H}_{2} \mathrm{~S}$ production at the tumor site was associated with the relative abundance of Fusobacterium nucleatum, a known $\mathrm{H}_{2} \mathrm{~S}$ producer largely suspected to promote colorectal cancer $(18,51,74,96,97)$. By using paired colon tumor and normal adjacent tissues from volunteers, it was found that sulfidogenic Fusobacterium nucleatum was enriched in the colon tumors of patient with deficient mismatch repair colorectal cancer (39). In accordance with these results, in African Americans, sulfidogenic bacteria abundance was higher in colonic tissue biopsies recovered from patients with colorectal cancer when compared with healthy subjects (99), thus further reinforcing the view that these bacteria represent a risk factor for colorectal cancer development. In addition, sulfurcontaining compounds in the samples of flatus recovered from patients with colorectal cancer were more abundant when compared with samples recovered from healthy subjects (98).

In vitro studies on the effects of $\mathrm{H}_{2} \mathrm{~S}$ on different cancerous colonic epithelial cell lines have used different $\mathrm{H}_{2} \mathrm{~S}$ donors (either fast- or slow releasing donors) at different concentrations and for different period of times. The interpretation and comparison of the different studies with different experimental protocols 
on that topic is complicated by the fact that $\mathrm{H}_{2} \mathrm{~S}$ in the culture medium is rapidly released in the gas phase in the culture flasks, thus decreasing within hours the $\mathrm{H}_{2} \mathrm{~S}$ concentration in the extracellular medium (53). In addition, the capacity of colonic epithelial cells to oxidize $\mathrm{H}_{2} \mathrm{~S}$ may affect, depending on their density in the flasks, the $\mathrm{H}_{2} \mathrm{~S}$ concentration in the culture media. Lastly, since some components of the culture media may bind $\mathrm{H}_{2} \mathrm{~S}$, the concentration of bioavailable hydrogen sulfide may differ from the theoretical values. With these reservations in mind, from the available studies, it appears that low concentrations of $\mathrm{H}_{2} \mathrm{~S}$ (micromolar) generally increase cell growth while higher concentrations (low millimolar) inhibit it. In the HCT116 colonic carcinoma cells, the $\mathrm{H}_{2} \mathrm{~S}$ donor GYY4137, used at $300 \mu \mathrm{M}$ concentration, enhanced cell respiration and glycolysis, as well as cell proliferation (87) (Figure 5). The stimulatory effect of $\mathrm{H}_{2} \mathrm{~S}$ on glycolysis was due to the persulfidation of lactate dehydrogenase, thus enhancing its catalytic activity. Using $200 \mu \mathrm{M}$ NaHS on the same cell line, the $\mathrm{H}_{2} \mathrm{~S}$ donor stimulated cell proliferation through an increased Akt and ERK activation (19). This effect was associated with a decreased expression of the cell cycle inhibitor p21/waf1/cip1. In good accordance with these latter results, increased endogenous production of $\mathrm{H}_{2} \mathrm{~S}$ in colorectal carcinoma cells was associated with increased proliferative capacity, since the allosteric CBS activator S-adenosyl-L-methionine, which increases as expected $\mathrm{H}_{2} \mathrm{~S}$ production in $\mathrm{HCT} 116$ cells, increased oxygen consumption and cell proliferation (61). Of note, in the cancerous subpopulation of parental HCT116 cells that are resistant to the chemotherapeutic agent 5 -fluorouracil, CBS is upregulated leading to increased capacity of these cells to produce $\mathrm{H}_{2} \mathrm{~S}(88)$. In addition, decreased expression of CBS in HCT116 cells reduces the cell growth, and the growth rate and size of HCT116 xenografts (84). In accordance with these results, pharmacological inhibition of CBS catalytic activity inhibits HCT116 oxygen consumption and glycolysis, an effect that was paralleled by a G0/G1 arrest responsible for a reduction of cell growth without loss of cell viability (20). In vivo, the silencing or pharmacological inhibition of CBS activity attenuate the growth of colon carcinoma cell xenografts in nude mice, as well as neovessel density, suggesting a role of endogenous $\mathrm{H}_{2} \mathrm{~S}$ in colorectal cancer cell growth and tumor angiogenesis (84).

Overall, the available studies suggest that an increased CBS activity and resulting increased $\mathrm{H}_{2} \mathrm{~S}$ production in colonic epithelial cells, or moderate supply of exogenous $\mathrm{H}_{2} \mathrm{~S}$, may participate in the promotion of colon carcinogenesis. However, increased CBS activity may not be the unique way by 
which colonocyte increase their $\mathrm{H}_{2} \mathrm{~S}$ production in the carcinogenesis process. Indeed, increased $\mathrm{H}_{2} \mathrm{~S}$ production in the CSE pathway is involved in the growth of colorectal cells. In fact, silencing or pharmacological inhibition of CSE in the colorectal cancer cells SW480 decreased the capacity of colorectal cancer cell to proliferate in vitro, and decreased tumor xenograft growth in vivo (27). Incidentally, the interpretation of the data are complicated by the fact that CBS and CSE pathways has been demonstrated as competing reactions for the production of $\mathrm{H}_{2} \mathrm{~S}(47)$.

In contrast, higher concentration of GYY4137 (3.0 mM) inhibited markedly the proliferation of HCT116 cells (66). In the cancerous HT-29 colonic epithelial cells, NaHS at $1 \mathrm{mM}$ concentration inhibited cell respiration and oxidation of glutamine and butyrate (53). These $\mathrm{H}_{2} \mathrm{~S}$ effects that coincided with a marked reduction of the cell proliferative capacity without cell viability loss, was paralleled by a spectacular increase of the glycolytic pathway. In this latter study, since the cells maintained their ATP cell content, it was proposed that by reducing cell growth, and thus ATP-consuming anabolic metabolism, and by enhancing glycolysis, the cell maintained their viability under restriction of mitochondrial ATP production (Figure 6). Spontaneous or butyrate-induced differentiated HT-29 cells were characterized by an increased capacity for sulfide oxidation when compared to highly proliferative cells, suggesting that high concentration of sulfide would affect more severely oxidative energy metabolism in proliferative than differentiated cancerous colon epithelial cells (60).

The in vitro studies by Attene-Ramos et al (4) have shown that exogenous $\mathrm{H}_{2} \mathrm{~S}$ is able to induce in vitro DNA single and double breaks in mammalian cells. However, recent in vivo studies have shown that $\mathrm{H}_{2} \mathrm{~S}$ at concentration found in the colonic luminal content are unlikely to be genotoxic for colonocytes in short-term experiments with rats (9). Further work is required to determine in what condition and context $\mathrm{H}_{2} \mathrm{~S}$ may alter genomic and mitochondrial DNA in colonic epithelial cells.

\section{Conclusion and perspectives}

Among the numerous compounds released by the microbiota in the colon and rectum, $\mathrm{H}_{2} \mathrm{~S}$ has emerged as one typical example of a metabolic end product that have an impact on the host colonic mucosa energy metabolism. The 
capacity of the colonocytes to cope with increasing concentration of unbound $\mathrm{H}_{2} \mathrm{~S}$ in the luminal content is dependent on its ability to oxidize this compound in the mitochondria by the SOU. This process allows to control the intracellular concentration within colonocytes and to use it as a rapid mineral energy substrate allowing it to participate to ATP production in a context of rapid epithelium renewal and associated intense anabolism. However, the capacity for sulfide disposal is intrinsically limited, and thus, in condition of increased unbound $\mathrm{H}_{2} \mathrm{~S}$ luminal concentration, the intracellular sulfide concentration may exceed the detoxifying capacity of colonocytes. In such a case, the surplus of $\mathrm{H}_{2} \mathrm{~S}$ concentration inhibits colonocyte respiration and ATP production in the mitochondria. However, colonocytes are not only exposed to $\mathrm{H}_{2} \mathrm{~S}$ originating from the lumen, but also from the one produced endogenously. Mostly due to inherent technical difficulties, there is still little information on the endogenous and exogenous origin of the intracellular $\mathrm{H}_{2} \mathrm{~S}$ concentration within colonocytes in different physiological and pathophysiological contexts. However, it is highly likely that the gut microbiota contributes much more than endogenous synthesis to $\mathrm{H}_{2} \mathrm{~S}$ intracellular concentration value (15).

Regarding the implication of $\mathrm{H}_{2} \mathrm{~S}$ in the process of chronic inflammatory bowel diseases, there are evidence from both clinical and experimental data that an excess of sulfide over the oxidative capacity of colonocytes participates in the inflammatory process. In addition, such an excessive luminal concentration of sulfide destabilizes the mucus layers, thus decreasing the protection of the colonic epithelium against this (and other) deleterious luminal compounds. However, restricting markedly the endogenous production of $\mathrm{H}_{2} \mathrm{~S}$ within colonocytes appears counterproductive as it favours the inflammatory process. Further work is needed to determine possible differences in the action of $\mathrm{H}_{2} \mathrm{~S}$ on colonic epithelial cells depending on its intracellular or extracellular origin.

Regarding the implication of $\mathrm{H}_{2} \mathrm{~S}$ in the process of colorectal carcinogenesis, recent studies have suggested that increased $\mathrm{H}_{2} \mathrm{~S}$ synthesis in adenoma-like colonic epithelial cells through higher CBS activity, increased their energy metabolism, proliferation, and tumorigenicity in animal models. From colonic biopsies recovered from volunteers, it appears that $\mathrm{H}_{2} \mathrm{~S}$ production is increased in colorectal cancer when compared with adjacent healthy tissues. The experiments performed in vitro with various cell lines recovered from colorectal cancer indicate that $\mathrm{H}_{2} \mathrm{~S}$ at micromolar concentration favours cell energy metabolism and proliferation. In such condition, cell energy metabolism is enhanced at the mitochondrial level, but also at the glycolytic level. 
Interestingly, such an increased glycolytic capacity was due to the persulfidation of lactate dehydrogenase, thus enhancing its catalytic activity. The meaning of this increased glycolysis for cell growth remains unclear giving the low ATP production from this metabolic pathway when compared to the mitochondrial ATP production from the respiratory chain, but it may relate to the synthesis of ribonucleotides and NADPH in the pentose phosphate pathway that is derived from glycolysis (68).

The process of protein persulfidation in colonic epithelial cells, as shown for LDH (86), may play an important role for explaining some of the $\mathrm{H}_{2} \mathrm{~S}$ effects. Thus, it appears plausible, but remained to be tested, that other cellular targets in colonocytes would be modified by this post-translational biochemical process. Just to take a first and stimulating example, a study performed in noncolonic cells, namely macrophages, has shown that $\mathrm{H}_{2} \mathrm{~S}$-linked persulfidation of NFkappaB is linked to an antiapoptotic signal in these cells (77). Also of interest, in colonic smooth muscle cells, $\mathrm{H}_{2} \mathrm{~S}$ acts through the persulfidation process as an allosteric modulator of the ATP-sensitive $\mathrm{K}^{+}$channels (31).

In contrast, higher $\mathrm{H}_{2} \mathrm{~S}$ concentrations in the low millimolar range inhibited cancerous colonocyte proliferation, an effect that may be seen at a first glance at a beneficious effect of $\mathrm{H}_{2} \mathrm{~S}$ in the context of the development of colorectal cancer. However, it appears that in such conditions, cancerous cells are able to maintain their ATP content by decreased proliferation and increased glycolysis, thus maintaining their viability. It is then tempting to propose from these experiments, that such processes would allow the cancerous cells to survive to an enhanced extracellular supply of $\mathrm{H}_{2} \mathrm{~S}$. It is worth noting however that conditions in which these in vitro experiments were performed are obviously very different from the in vivo conditions, considering the great heterogeneity of cells in the colorectal tumors $(76)$ and of their microenvironment $(17,49)$.

Regarding the effects of endogenous and exogenous $\mathrm{H}_{2} \mathrm{~S}$ on the process of stimulus-secretion coupling in enteroendocrine cells of the colon, the mechanisms involved in such a process remains poorly known. Advantages could be taken in future studies from some comparison with studies devoted to the role of $\mathrm{H}_{2} \mathrm{~S}$ on insulin secretion, because of some proximity between EEC and pancreatic beta cells. Also, taking into account that $\mathrm{H}_{2} \mathrm{~S}$ can either, depending on its concentration, stimulates or inhibits mitochondrial ATP production, it would be of interest to determine to what extent modulation of 
energy metabolism in EEC may participate in the effect of $\mathrm{H}_{2} \mathrm{~S}$ on enteroendocrine hormone secretion in the colon.

538 In conclusion, the available data from clinical and in vivo/in vitro experimental works indicate that endogenous and microbiota-derived $\mathrm{H}_{2} \mathrm{~S}$ have major impact on the colonic epithelial cells, notably in terms of energy metabolism. This is observed in healthy situation but also in the context of inflammatory bowel diseases and colorectal carcinogenesis. Then, reduction of excessive luminal $\mathrm{H}_{2} \mathrm{~S}$ concentration and/or excessive endogenous production by targeted pharmacological approaches in colonic epithelial cells, may prove to have some efficacy in reducing its deleterious effects on the colonic mucosa. However, given the ambivalent nature of the effects of $\mathrm{H}_{2} \mathrm{~S}$ on these cells, either beneficial or deleterious according to its intracellular concentration in a given physiological or pathophysiological context, this strategy can be considered as risky. Thus, in condition of excessive production, reduction of the number of $\mathrm{H}_{2} \mathrm{~S}$ producing-intestinal bacteria and/or limitation by dietary means of the supply of S-containing substrates for $\mathrm{H}_{2} \mathrm{~S}$ production, may represent a more strategic approach.

Acknowledgments

This work was supported by the Université Paris-Saclay, AgroParisTech, INRAE, and by the National Research Foundation of Korea under grant agreement NRF2019R1A2C1009216

\section{References}

1. Andriamihaja M, Lan A, Beaumont M, Grauso M, Gotteland M, Pastene E, containing polyphenol extracts from fruits prevent the inhibitory effect of hydrogen sulfide on human colonocyte oxygen consumption. Amino Acids. 2018;50(6):755-763. doi:10.1007/s00726-018-2558-y 
2. Arijs I, Vanhove W, Rutgeerts P, Schuit F, Verbeke K, De Preter V. Decreased mucosal sulfide detoxification capacity in patients with Crohn's disease. Inflamm Bowel Dis. 2013;19(5):E70-E72. doi:10.1097/MIB.0b013e31827e790e

3. Arora T, Akrami R, Pais R, Bergqvist L, Johansson BR, Schwartz TW, Reimann F, Gribble FM, Backed F. Microbial regulation of the $L$ cell transcriptome. Sci Rep. 2018;8(1):1207. doi:10.1038/s41598-017-180792

4. Attene-Ramos MS, Nava GM, Muellner MG, Wagner ED, Plewa MJ, Gaskins HR. DNA damage and toxicogenomic analyses of hydrogen sulfide in human intestinal epithelial $\mathrm{FHs} 74 \mathrm{Int}$ cells. Environ Mol Mutagen. 2010;51(4):304-314. doi:10.1002/em.20546

5. Babidge W, Millard S, Roediger W. Sulfides impair short chain fatty acid beta-oxidation at acyl-CoA dehydrogenase level in colonocytes: implications for ulcerative colitis. Mol Cell Biochem. 1998;181(1-2):117124. doi:10.1023/a:1006838231432

6. Bachmann $\mathrm{O}$, Juric $\mathrm{M}$, Seidler $\mathrm{U}$, Manns MP, Yu H. Basolateral ion transporters involved in colonic epithelial electrolyte absorption, anion secretion and cellular homeostasis. Acta Physiol (Oxf). 2011;201(1):3346. doi:10.1111/j.1748-1716.2010.02153.x

7. Bala V, Rajagopal S, Kumar DP, Nalli AD, Mahavadi S, Sanyal AJ, Grider JR, Murthy KS. Release of GLP-1 and PYY in response to the activation of G protein-coupled bile acid receptor TGR5 is mediated by Epac/PLC- $\varepsilon$ pathway and modulated by endogenous H2S. Front Physiol. 2014;5:420. doi:10.3389/fphys.2014.00420

8. Barton LL, Ritz NL, Fauque GD, Lin HC. Sulfur Cycling and the Intestinal Microbiome. Dig Dis Sci. 2017;62(9):2241-2257. doi:10.1007/s10620017-4689-5

9. Beaumont $M$, Andriamihaja $M$, Lan $A$, Khodorova $N$, Audebert $M$, Blouin JM, Grauso M, Lancha L, Benetti PH, Benamouzig R, Tomé D, Bouillaud F, Davila AM, Blachier F. Detrimental effects for colonocytes of an increased exposure to luminal hydrogen sulfide: The adaptive response. Free Radic Biol Med. 2016;93:155-164. doi:10.1016/j.freeradbiomed.2016.01.028

10. Billing LJ, Larraufie P, Lewis J, Leiter A, Li J, Lam B, Yeo GS, Goldpink DA, Kay RG, Gribble FM, Reimann F. Single cell transcriptomic profiling of large intestinal enteroendocrine cells in mice - Identification of selective stimuli for insulin-like peptide-5 and glucagon-like peptide-1 co- 
expressing cells. Mol Metab.

2019;29:158-169. doi:10.1016/j.molmet.2019.09.001

11.Blachier F, Mariotti F, Huneau JF, Tomé D. Effects of amino acid-derived luminal metabolites on the colonic epithelium and physiopathological consequences. Amino Acids. 2007;33(4):547-562. doi:10.1007/s00726006-0477-9

12.Blachier F, Boutry C, Bos C, Tomé D. Metabolism and functions of Lglutamate in the epithelial cells of the small and large intestines. Am J Clin Nutr. 2009;90(3):814S-821S. doi:10.3945/ajcn.2009.27462S

13. Blachier F, Davila AM, Mimoun S, Benetti PH, Atanasiu C, Andriamihaja $M$, Benamouzig $R$, Bouillaud $F$, Tomé $D$. Luminal sulfide and large intestine mucosa: friend or foe?. Amino Acids. 2010;39(2):335-347. doi:10.1007/s00726-009-0445-2

14.Blachier F, Beaumont M, Andriamihaja M, Davila AM, Lan A, Grauso M, Armand L, Benamouzig R, Tomé D. Changes in the Luminal Environment of the Colonic Epithelial Cells and Physiopathological Consequences. Am J Pathol. 2017;187(3):476-486. doi:10.1016/j.ajpath.2016.11.015

15. Blachier F, Beaumont M, Kim E. Cysteine-derived hydrogen sulfide and gut health: a matter of endogenous or bacterial origin. Curr Opin Clin Nutr Metab Care. 2019;22(1):68-75. doi:10.1097/MCO.0000000000000526

16. Bouillaud F, Blachier F. Mitochondria and sulfide: a very old story of poisoning, feeding, and signaling?. Antioxid Redox Signal. 2011;15(2):379-391. doi:10.1089/ars.2010.3678

17. Brown RE, Short SP, Williams CS. Colorectal Cancer and Metabolism. Curr Colorectal Cancer Rep. 2018;14(6):226-241. doi:10.1007/s11888-0180420-y

18. Bullman S, Pedamallu CS, Sicinska E, Clancy TE, Zhang X, Cai D, Neuberg D, Huang K, Guevara F, Nelson T, Chipashvili O, Hagan T, Walker M, Ramachandran A, Diosdado B, Serna G, Mulet N, Landolfi S, Ramon $Y$ Cajal S, Fasani R, Aguirre AJ, Ng K, Elez E, Ogino S, Tabernero J, Fuchs CS, Hahn WC, Nuciforo P, Meyerson M. Analysis of Fusobacterium persistence and antibiotic response in colorectal cancer. Science. 2017;358(6369):1443-1448. doi:10.1126/science.aal5240

19.Cai WJ, Wang MJ, Ju LH, Wang C, Zhu YC. Hydrogen sulfide induces human colon cancer cell proliferation: role of Akt, ERK and p21. Cell Biol 
Int. 2010;34(6):565-572. Published 2010 Apr 14. doi:10.1042/CBI20090368

20.Chao C, Zatarain JR, Ding Y, Coletta C, Mrazek AA, Druzhyna N, Johnson $P$, Chen $\mathrm{H}$, Hellmich JL, Asimakopoulou A, Yanagi K, Olah G, Szoleczky P, Toro G, Bohanon FJ, Cheema M, Lewis R, Eckelbarger D, Ahmad A, Modis K, Untereiner A, Szczesny B, Papapetropoulos A, Zhou J, Hellmich MR, Szabo C. Cystathionine-beta-synthase inhibition for colon cancer: Enhancement of the efficacy of aminooxyacetic acid via the prodrug approach. Mol Med. 2016;22:361-379. doi:10.2119/molmed.2016.00102

21.Chen S, Bu D, Ma Y, Zhu J, Sun L, Zuo S, Ma J, Li T, Chen Z, Zheng Y, Wang $X$, Pan Y, Wang P, Liu Y. GYY4137 ameliorates intestinal barrier injury in a mouse model of endotoxemia. Biochem Pharmacol. 2016;118:59-67. doi:10.1016/j.bcp.2016.08.016

22. Cooper CE, Brown GC. The inhibition of mitochondrial cytochrome oxidase by the gases carbon monoxide, nitric oxide, hydrogen cyanide and hydrogen sulfide: chemical mechanism and physiological significance. J Bioenerg Biomembr. 2008;40(5):533-539. doi:10.1007/s10863-008-9166-6

23. Davila AM, Blachier F, Gotteland M, Andriamihaja M, Benetti PH, Sanz Y, Tomé D. Intestinal luminal nitrogen metabolism: role of the gut microbiota and consequences for the host. Pharmacol Res. 2013;68(1):95-107. doi:10.1016/j.phrs.2012.11.005

24.De Mey JR, Freund JN. Understanding epithelial homeostasis in the intestine: An old battlefield of ideas, recent breakthroughs and remaining controversies. Tissue Barriers. 2013;1(2):e24965. doi:10.4161/tisb.24965

25. Drucker NA, Jensen AR, Te Winkel JP, Markel TA. Hydrogen Sulfide Donor GYY4137 Acts Through Endothelial Nitric Oxide to Protect Intestine in Murine Models of Necrotizing Enterocolitis and Intestinal Ischemia.J Surg Res. 2019;234:294-302. doi:10.1016/j.jss.2018.08.048

26. Evenepoel P, Claus D, Geypens B, Hiele M, Geboes K, Rutgeerts P, Ghoos $\mathrm{Y}$. Amount and fate of egg protein escaping assimilation in the small intestine of humans. Am J Physiol. 1999;277(5):G935-G943. doi:10.1152/ajpgi.1999.277.5.G935

27.Fan K, Li N, Qi J, Yin P, Zhao C, Wang L, Li Z, Zha X. Wnt/ $\beta$-catenin signaling induces the transcription of cystathionine- $\gamma$-lyase, a stimulator of tumor in colon cancer. Cell Signal. 2014;26(12):2801-2808. doi:10.1016/j.cellsig.2014.08.023 
28. Flannigan KL, McCoy KD, Wallace JL. Eukaryotic and prokaryotic contributions to colonic hydrogen sulfide synthesis. Am J Physiol 2011;301:G188-G193.

doi: 10.1152/ajpgi.00105.2011

29. Flannigan KL, Agbor TA, Motta JP, Ferraz JGP, Wang R, Buret AG, Wallace $\mathrm{JL}$. Proresolution effects of hydrogen sulfide during colitis are mediated through hypoxia-inducible factor-1 $\alpha$. FASEB J. 2015;29(4):1591-1602. doi:10.1096/fj.14-266015

30. Forte E, Borisov VB, Falabella M, Colaco HG, Tinajero-Trejo M, Poole RK, Vicente JB, Sarti P, Giuffre A. The terminal oxidase cytochrome bd promotes sulfide-resistant bacterial respiration and growth. Sci Rep. $2016 ; 6: 23788$. doi :10.1038/srep23788

31.Gade AR, Kang M, Akbarali HI. Hydrogen sulfide as an allosteric modulator of ATP-sensitive potassium channels in colonic inflammation. Mol Pharmacol. 2013;83(1):294-306. doi:10.1124/mol.112.081596

32.Gecse KB, Vermeire S. Differential diagnosis of inflammatory bowel disease: imitations and complications. Lancet Gastroenterol Hepatol. 2018;3(9):644-653. doi:10.1016/S2468-1253(18)30159-6

33.Giuffrè A, Vicente JB. Hydrogen Sulfide Biochemistry and Interplay with Other Gaseous Mediators in Mammalian Physiology. Oxid Med Cell Longev. 2018;2018:6290931. doi:10.1155/2018/6290931

34.Goubern M, Andriamihaja M, Nübel T, Blachier F, Bouillaud F. Sulfide, the first inorganic substrate for human cells. FASEB J. 2007;21(8):1699-1706. doi:10.1096/fj.06-7407com

35.Gribble FM, Reimann F. Function and mechanisms of enteroendocrine cells and gut hormones in metabolism. Nat Rev Endocrinol. 2019;15(4):226-237. doi:10.1038/s41574-019-0168-8

36.Guo FF, Yu TC, Hong J, Fang JY. Emerging Roles of Hydrogen Sulfide in Inflammatory and Neoplastic Colonic Diseases. Front Physiol. 2016;7:156. doi:10.3389/fphys.2016.00156

37.Guo W, Kan JT, Cheng ZY, Chen JF, Shen YQ, Xue J, Wu D, Zhu YZ. Hydrogen sulfide as an endogenous modulator in mitochondria and mitochondria dysfunction. Oxid Med Cell Longev. 2012;2012:878052. doi:10.1155/2012/878052

38. Hale VL, Jeraldo P, Mundy M, Yao J, Keeney G, Scott N, Heidi Cheek E, Davidson J, Greene M, Martinez C, Lehman J, Pettry C, Reed E, Lyke K, 
White BA, Diener C, Resendis-Antonio O, Gransee J, Dutta T, Petterson $X M$, Boardman L, Larson D, Nelson H, Chia N. Synthesis of multi-omic data and community metabolic models reveals insights into the role of hydrogen sulfide in colon cancer. Methods. 2018;149:59-68. doi:10.1016/j.ymeth.2018.04.024

39. Hale VL, Jeraldo P, Chen J, Mundy M, Yao J, Priya S, Keeney G, Lyke K, Ridlon J, White BA, French AJ, Thibodeau SN, Diener C, Resendis-Antonio O, Gransee J, Dutta T, Petterson XM, Sung J, Blekhman R, Boardman L, Larson D, Nelson H, Chia N. Distinct microbes, metabolites, and ecologies define the microbiome in deficient and proficient mismatch repair colorectal cancers. Genome Med. 2018;10(1):78. doi:10.1186/s13073018-0586-6

40. Hirata I, Naito Y, Takagi T, Mizushima K, Suzuki T, Omatsu T, Handa O, Ichikawa $\mathrm{H}$, Ueda $\mathrm{H}$, Yoshikawa T. Endogenous hydrogen sulfide is an anti-inflammatory molecule in dextran sodium sulfate-induced colitis in mice. Dig Dis Sci. 2011;56(5):1379-1386. doi:10.1007/s10620-010-1461-5

41.Hyspler R, Tichá A, Indrová M, Zadak Z, Hysplerova L, Gasparic J, Churacek J. A simple, optimized method for the determination of sulphide in whole blood by GC-mS as a marker of bowel fermentation processes. J Chromatogr B Analyt Technol Biomed Life Sci. 2002;770(12):255-259. doi:10.1016/s1570-0232(01)00632-8

42.ljssennagger N, Belzer C, Hooiveld GJ, Dekker J, van Mil SWC, Muller M, Kleerebezem M, van der Meer R. Gut microbiota facilitates dietary heme-induced epithelial hyperproliferation by opening the mucus barrier in colon. Proc Natl Acad Sci U S A. 2015;112(32):10038-10043. doi:10.1073/pnas.1507645112

43.Jensen B, Fago A. Reactions of ferric hemoglobin and myoglobin with hydrogen sulfide under physiological conditions.J Inorg Biochem. 2018;182:133-140. doi:10.1016/j.jinorgbio.2018.02.007

44.Johansson ME, Hansson GC. Immunological aspects of intestinal mucus and mucins. Nat Rev Immunol. 2016;16(10):639-649. doi:10.1038/nri.2016.88

45.Jørgensen J, Mortensen PB. Hydrogen sulfide and colonic epithelial metabolism: implications for ulcerative colitis. Dig Dis Sci. 2001;46(8):1722-1732. doi:10.1023/a:1010661706385

46.Jowett SL, Seal CJ, Pearce MS, Phillips E, Gregory W, Barton JR, Welfare $M R$. Influence of dietary factors on the clinical course of ulcerative colitis: 
a prospective cohort study. Gut. 2004;53(10):1479-1484. doi:10.1136/gut.2003.024828

47. Kabil O, Yadav V, Banerjee R. Heme-dependent metabolite swithching regulates $\mathrm{H} 2 \mathrm{~S}$ synthesis in response to endoplasmic reticulum (ER) stress. J Biol Chem. 2016;291:16418-16423. doi: 10.1074/jbc.C116.742213

48. Kaser A, Zeissig S, Blumberg RS. Inflammatory bowel disease. Annu Rev Immunol. 2010;28:573-621. doi:10.1146/annurev-immunol-030409101225

49. Katoh M. Canonical and non-canonical WNT signaling in cancer stem cells and their niches: Cellular heterogeneity, omics reprogramming, targeted therapy and tumor plasticity. Int J Oncol. 2017;51(5):1357-1369. doi:10.3892/ijo.2017.4129

50. Khor B, Gardet A, Xavier RJ. Genetics and pathogenesis of inflammatory bowel disease. Nature. 2011;474(7351):307-317. doi:10.1038/nature10209

51.Kostic AD, Chun E, Robertson L, Glickman JN, Gallini CA, Michaud M, Clancy TE, Chung DC, Lochhead P, Hold GL, El-Omar EM, Brenner D, Fuchs CS, Meyerson M, Garrett WS. Fusobacterium nucleatum potentiates intestinal tumorigenesis and modulates the tumor-immune microenvironment. Cell Host Microbe. 2013;14(2):207-215. doi:10.1016/j.chom.2013.07.007

52. Larraufie $P$, Doré J, Lapaque $N$, Blottière HM. TLR ligands and butyrate increase Pyy expression through two distinct but inter-regulated pathways. Cell Microbiol. 2017;19(2):10.1111/cmi.12648. doi:10.1111/cmi.12648

53.Leschelle X, Goubern M, Andriamihaja M, Blottiere HM, Couplan E, Gonzalez-Barroso MDM, Petit C, Pagniez A, Chaumontet C, Mignotte B, Bouillaud F, Blachier F. Adaptative metabolic response of human colonic epithelial cells to the adverse effects of the luminal compound sulfide. Biochim Biophys Acta. 2005;1725(2):201-212. doi:10.1016/j.bbagen.2005.06.002

54. Levine J, Ellis CJ, Furne JK, Springfield J, Levitt MD. Fecal hydrogen sulfide production in ulcerative colitis. Am J Gastroenterol. 1998;93(1):83-87. doi:10.1111/j.1572-0241.1998.083_c.x

55. Levitt MD, Springfield J, Furne J, Koenig T, Suarez FL. Physiology of sulfide in the rat colon: use of bismuth to assess colonic sulfide production. J Appl Physiol (1985). 2002;92(4):1655-1660. doi:10.1152/japplphysiol.00907.2001 
56. Levitt MD, Furne J, Springfield J, Suarez F, DeMaster E. Detoxification of hydrogen sulfide and methanethiol in the cecal mucosa. J Clin Invest. 1999;104(8):1107-1114. doi:10.1172/JCI7712

57.Lewis JE, Miedzybrodzka EL, Foreman RE, Woodward OR, Kay RG, Goldspink DA, Gribble FM, Reimann F. Selective stimulation of colonic L cells improves metabolic outcomes in mice. Diabetologia. 2020;63(7):1396-1407. doi:10.1007/s00125-020-05149-w

58. Libiad M, Vitvitsky V, Bostelaar T, Bak DW, Lee HJ, Sakamoto N, Fearon E, Lyssiotis CA, Weerapana E, Banerjee R. Hydrogen sulfide perturbs mitochondrial bioenergetics and triggers metabolic reprogramming in colon cells. J Biol Chem. 2019;294(32):12077-12090. doi:10.1074/jbc.RA119.009442

59. Magee EA, Richardson CJ, Hughes R, Cummings JH. Contribution of dietary protein to sulfide production in the large intestine: an in vitro and a controlled feeding study in humans. Am J Clin Nutr. 2000;72(6):14881494. doi:10.1093/ajen/72.6.1488

60. Mimoun S, Andriamihaja M, Chaumontet C, Atanasiu C, Benamouzig R, Blouin JM, Tomé D, Bouillaud F, Blachier F. Detoxification of H(2)S by differentiated colonic epithelial cells: implication of the sulfide oxidizing unit and of the cell respiratory capacity. Antioxid Redox Signal. 2012;17(1):1-10. doi:10.1089/ars.2011.4186

61.Módis K, Coletta C, Asimakopoulou A, Szczesny B, Chao C, Papapetropoulos A, Hellmich M, Szabo C. Effect of S-adenosyl-Lmethionine (SAM), an allosteric activator of cystathionine- $\beta$-synthase (CBS) on colorectal cancer cell proliferation and bioenergetics in vitro. Nitric Oxide. 2014;41:146-156. doi:10.1016/j.niox.2014.03.001

62. Motta JP, Flannigan KL, Agbor TA, et Beatty JK, Blackler RW, Workentine ML, Da Silva GJ, Wang R, Buret AG, Wallace JL. Hydrogen sulfide protects from colitis and restores intestinal microbiota biofilm and mucus production. Inflamm Bowel Dis. 2015;21(5):1006-1017. doi:10.1097/MIB.0000000000000345

63. Mottawea W, Chiang CK, Mühlbauer M, Starr AE, Butcher J, Abujamel T, Deeke SA, Brandel A, Zhou H, Shokralla S, Hajibabaei M, Singleton R, Benchimol El, Jobin C, Mack DR, Figeys D, Stinzi A. Altered intestinal microbiota-host mitochondria crosstalk in new onset Crohn's disease. Nat Commun. 2016;7:13419. doi:10.1038/ncomms13419

64.Nadjsombati MS, McGinty JW, Lyons-Cohen MR, Jaffe JB, DiPeso L, Schneider C, Miller CN, Pollack JL, Nagana Gowda GA, Fontana MF, Erle 
DJ, Anderson MS, Locksley RM, Raftery D, von Moltke J. Detection of Succinate by Intestinal Tuft Cells Triggers a Type 2 Innate Immune Circuit. Immunity.

2018;49(1):33-41.e7. doi:10.1016/j.immuni.2018.06.016

65. Nicholls P, Marshall DC, Cooper CE, Wilson MT. Sulfide inhibition of and metabolism by cytochrome $c$ oxidase. Biochem Soc Trans. 2013;41(5):1312-1316. doi:10.1042/BST20130070

66. Oláh G, Módis K, Törö G, Hellmich MR, Szczesny B, Szabo C. Role of endogenous and exogenous nitric oxide, carbon monoxide and hydrogen sulfide in HCT116 colon cancer cell proliferation. Biochem Pharmacol. 2018;149:186-204. doi:10.1016/j.bcp.2017.10.011

67. Owczarek D, Rodacki T, Domagała-Rodacka R, Cibor D, Mach T. Diet and nutritional factors in inflammatory bowel diseases. World J Gastroenterol. 2016;22(3):895-905. doi:10.3748/wjg.v22.i3.895

68.Patra KC, Hay N. The pentose phosphate pathway and cancer. Trends Biochem Sci. 2014;39(8):347-354. doi:10.1016/j.tibs.2014.06.005

69.Phillips CM, Zatarain JR, Nicholls ME, Porter C, Widen SG, Thanki K, Johnson P, Jawad MU, Moyer MP, Randall JW, Hellmich JL, Maskey M, Qiu S, Wood TG, Druzhyna N, Szczesny B, Modis K, Szabo C, Chao C, Hellmich MR. Upregulation of Cystathionine- $\beta$-Synthase in Colonic Epithelia Reprograms Metabolism and Promotes Carcinogenesis. Cancer Res. 2017;77(21):5741-5754. doi:10.1158/0008-5472.CAN-16-3480

70.Pichette J, Fynn-Sackey N, Gagnon J. Hydrogen Sulfide and Sulfate Prebiotic Stimulates the Secretion of GLP-1 and Improves Glycemia in Male Mice. Endocrinology. 2017;158(10):3416-3425. doi:10.1210/en.2017-00391

71.Qin $\mathrm{M}$, Long $\mathrm{F}$, Wu W, Yang D, Huang $\mathrm{M}$, Xiao C, Chen X, Liu X, Zhu YZ. Hydrogen sulfide protects against DSS-induced colitis by inhibiting NLRP3 inflammasome. Free Radic Biol Med. 2019;137:99-109. doi:10.1016/j.freeradbiomed.2019.04.025

72. Rabus R, Venceslau SS, Wöhlbrand L, Voordouw G, Wall JD, Pereira IA. A Post-Genomic View of the Ecophysiology, Catabolism and Biotechnological Relevance of Sulphate-Reducing Prokaryotes. Adv Microb Physiol. 2015;66:55-321. doi:10.1016/bs.ampbs.2015.05.002

73. Reiffenstein RJ, Hulbert WC, Roth SH. Toxicology of hydrogen sulfide. Annu Rev Pharmacol Toxicol. 1992;32:109-134. doi:10.1146/annurev.pa.32.040192.000545 
74. Rubinstein MR, Baik JE, Lagana SM, Han RP, Raab WJ, Sahoo D, Dalerba $P$, Wang TC, Han YW. Fusobacterium nucleatum promotes colorectal cancer by inducing Wnt/ $\beta$-catenin modulator Annexin A1. EMBO Rep. 2019;20(4):e47638. doi:10.15252/embr.201847638

75.Scott KP, Gratz SW, Sheridan PO, Flint HJ, Duncan SH. The influence of diet on the gut microbiota. Pharmacol Res. 2013;69(1):52-60. doi:10.1016/j.phrs.2012.10.020

76.Sasaki N, Clevers H. Studying cellular heterogeneity and drug sensitivity in colorectal cancer using organoid technology. Curr Opin Genet Dev. 2018;52:117-122. doi:10.1016/j.gde.2018.09.001

77.Sen N, Paul BD, Gadalla MM, Mustafa AK, Sen T, Xu R, Kim S, Snyder SH. Hydrogen sulfide-linked sulfhydration of NF-KB mediates its antiapoptotic actions. Mol Cell. 2012;45(1):13-24. doi:10.1016/j.molcel.2011.10.021

78.Shanmugathasan $\mathrm{M}$, Jothy $\mathrm{S}$. Apoptosis, anoikis and their relevance to the pathobiology of colon cancer. Pathol Int. 2000;50(4):273-279. doi:10.1046/j.1440-1827.2000.01047.x

79.Shen X, Carlström M, Borniquel S, Jädert C, Kevil CG, Lundberg JO. Microbial regulation of host hydrogen sulfide bioavailability and metabolism. Free Radic Biol Med. 2013;60:195-200. doi:10.1016/j.freeradbiomed.2013.02.024

80.Singer II, Kawka DW, Scott S, Weidner JR, Mumford RA, Riehl TE, Stenson WF. Expression of inducible nitric oxide synthase and nitrotyrosine in colonic epithelium in inflammatory bowel disease. Gastroenterology. 1996;111(4):871-885. doi:10.1016/s0016-5085(96)70055-0

81.Slade E, Williams L, Gagnon J. Hydrogen sulfide suppresses ghrelin secretion invitro and delays postprandial ghrelin secretion while reducing appetite in mice. Physiol Rep. 2018;6(19):e13870. doi:10.14814/phy2.13870

82. Song Y, Koehler JA, Baggio LL, Powers AC, Sandoval DA, Drucker DJ. GutProglucagon-Derived Peptides Are Essential for Regulating Glucose Homeostasis in Mice. Cell Metab. 2019;30(5):976-986.e3. doi:10.1016/j.cmet.2019.08.009

83. Suarez F, Furne J, Springfield J, Levitt M. Production and elimination of sulfur-containing gases in the rat colon. Am J Physiol. 1998;274(4):G727G733. doi:10.1152/ajpgi.1998.274.4.G727

84.Szabo C, Coletta C, Chao C, Modis K, Szczesny B, Papapetropoulos A, Hellmich MR. Tumor-derived hydrogen sulfide, produced by 
cystathionine- $\beta$-synthase, stimulates bioenergetics, cell proliferation, and angiogenesis in colon cancer. Proc Natl Acad Sci U S A. 2013;110(30):12474-12479. doi:10.1073/pnas.1306241110

85.Tiranti V, Viscomi C, Hildebrandt T, Di Meo I, Mineri S, Tiveron C, Levitt MD, Prelle A, Fagiolari G, Rimoldi M, Zeviani M. Loss of ETHE1, a mitochondrial dioxygenase, causes fatal sulfide toxicity in ethylmalonic encephalopathy. Nat Med. 2009;15(2):200-205. doi:10.1038/nm.1907

86. Tolhurst G, Heffron H, Lam YS, Parker HE, Habib AM, Diakogiannaki E, Cameron J, Grosse J, Reimann F, Gribble FM. Short-chain fatty acids stimulate glucagon-like peptide-1 secretion via the G-protein-coupled receptor FFAR2. Diabetes. 2012;61(2):364-371. doi:10.2337/db11-1019

87. Untereiner AA, Oláh G, Módis K, Hellmich MR, Szabo C. $\mathrm{H}_{2} \mathrm{~S}$-induced Ssulfhydration of lactate dehydrogenase a (LDHA) stimulates cellular bioenergetics in HCT116 colon cancer cells. Biochem Pharmacol. 2017;136:86-98. doi:10.1016/j.bcp.2017.03.025

88. Untereiner AA, Pavlidou A, Druzhyna N, Papapetropoulos A, Hellmich $\mathrm{MR}$, Szabo $\mathrm{C}$. Drug resistance induces the upregulation of $\mathrm{H}_{2} \mathrm{~S}$-producing enzymes in HCT116 colon cancer cells. Biochem Pharmacol. 2018;149:174-185. doi:10.1016/j.bcp.2017.10.007

89.van der Flier LG, Clevers H. Stem cells, self-renewal, and differentiation in the intestinal epithelium. Annu Rev Physiol. 2009;71:241-260. doi:10.1146/annurev.physiol.010908.163145

90.van der Wielen N, Moughan PJ, Mensink M. Amino Acid Absorption in the Large Intestine of Humans and Porcine Models.J Nutr. 2017;147(8):1493-1498. doi:10.3945/jn.117.248187

91.Vicente JB, Colaço HG, Mendes MI, Sarti P, Leandro P, Giuffrè A. NO* binds human cystathionine $\beta$-synthase quickly and tightly. J Biol Chem. 2014;289(12):8579-8587. doi:10.1074/jbc.M113.507533

92.Vidal-Lletjós $S$, Beaumont $M$, Tomé $D$, Benamouzig $R$, Blachier $F$, Lan A. Dietary Protein and Amino Acid Supplementation in Inflammatory Bowel Disease Course: What Impact on the Colonic Mucosa?. Nutrients. 2017;9(3):310. doi:10.3390/nu9030310

93. Visconti A, Le Roy Cl, Rosa F, Rossi N, Martin TC, Mohney RP, Li W, de Rinaldis E, Bell JT, Craig Venter J, Nelson KE, Spector TD, Falchi M. Interplay between the human gut microbiome and host metabolism. Nat Commun. 2019;10(1):4505. doi:10.1038/s41467-019-12476-z

94. Wallace JL, Vong L, McKnight W, Dicay M, Martin GR. Endogenous and exogenous hydrogen sulfide promotes resolution of colitis in rats. 
Gastroenterology. 2009;137(2):569-578.e1.

doi:10.1053/j.gastro.2009.04.012

95.Watanabe O, Ando T, Maeda O, Hasegawa M, Ishikawa D, Ishiguro K, Ohmiya N, Niwa Y, Goto H. Confocal endomicroscopy in patients with ulcerative colitis. J Gastroenterol Hepatol. 2008;23 Suppl 2:S286-S290. doi:10.1111/j.1440-1746.2008.05559.x

96. Yang $Y$, Weng $W$, Peng J, Hong L, Yang L, Toiyama Y, Gao R, Liu M, Yin M, Pan C, Li H, Guo B, Zhu Q, Wei Q, Moyer MP, Wang P, Cai S, Goel A, Qin $\mathrm{H}$, Ma Y. Fusobacterium nucleatum Increases Proliferation of Colorectal Cancer Cells and Tumor Development in Mice by Activating Toll-Like Receptor 4 Signaling to Nuclear Factor-kB, and Up-regulating Expression of MicroRNA-21. Gastroenterology. 2017;152(4):851-866.e24. doi:10.1053/j.gastro.2016.11.018

97.Yachida S, Mizutani S, Shiroma H, Shiba S, Nakajima T, Sakamoto T, Watanabe H, Masuda K, Nishimoto $Y$, Kubo M, Hosoda F, Rokutan H, Matsumoto M, Takamaru H, Yamada H, Matsuda T, Iwasaki M, Yamaji T, Yachida T, Soga T, Kurokawa K, Toyoda A, Ogura $Y$, Hayashi T, Hatakeyama M, Nakagama H, Saito $Y$, Fukuda S, Shibata T, Yamada T. Metagenomic and metabolomic analyses reveal distinct stage-specific phenotypes of the gut microbiota in colorectal cancer. Nat Med. 2019;25(6):968-976. doi:10.1038/s41591-019-0458-7

98.Yamagishi K, Onuma K, Chiba Y, Yagi S, Aoki S, Sato T, Sugawara Y, Hosoya N, Saeki Y, Takahashi M, Fuji M, Ohsaka T, Okajima T, Akita K, Suzuki T, Senawongse $P$, Urushiyma $H$, Sugiyama $S$, Nakajima $M$, Tsuboi $M$, Yamanaka T. Generation of gaseous sulfur-containing compounds in tumour tissue and suppression of gas diffusion as an antitumour treatment. Gut. 2012;61(4):554-561. doi:10.1136/gutjnl-2011-300721

99. Yazici C, Wolf PG, Kim H, Cross TWL, Vermillion K, Carroll T, Augustus GJ, Mutlu E, Tussing-Humphreys L, Braunschweig C, Xicola RM, Jung B, Llor X, Ellis NA, Rex Gaskins HR. Race-dependent association of sulfidogenic bacteria with colorectal cancer. Gut. 2017;66(11):1983-1994. doi:10.1136/gutjnl-2016-313321

100. Zhao H, Yan R, Zhou X, Ji F, Zhang B. Hydrogen sulfide improves colonic barrier integrity in DSS-induced inflammation in Caco-2 cells and mice. Int Immunopharmacol.

2016;39:121-127. doi:10.1016/j.intimp.2016.07.020 
Figure legends

Figure 1. Production of hydrogen sulfide by the colonic microbiota and by the colonic absorptive epithelial cells. This schematic representation recapitulates the main luminal substrates that are used by the colonic microbiota for $\mathrm{H}_{2} \mathrm{~S}$ synthesis, the different forms of $\mathrm{H}_{2} \mathrm{~S}$ in the luminal content, and the main metabolic pathway for endogenous $\mathrm{H}_{2} \mathrm{~S}$ synthesis in colonocytes. CBS, cystathionine beta-synthase.

Figure 2. Mitochondrial oxidation of hydrogen sulfide in mammalian cells. This schematic representation recapitulates the sulfide oxidation unit that allows the conversion of low concentrations of endogenous or exogenous $\mathrm{H}_{2} \mathrm{~S}$ into thiosulfate, and the synthesis of ATP in the mitochondrial respiratory chain (left part of the figure); and the inhibition of complex IV by high concentration of exogenous $\mathrm{H}_{2} \mathrm{~S}$ (right part of the figure). ETHE1, persulfide dioxygenase; $\mathrm{H}_{2} \mathrm{~S}_{2} \mathrm{O}_{3}$, thiosulfate; SQR, Sulfide Quinone Reductase.

Figure 3. Schematic representation of the inflammatory effect of luminal hydrogen sulfide in excess on colonocytes. When the metabolic capacity for $\mathrm{H}_{2} \mathrm{~S}$ synthesis by the colonic microbiota, due to either changes in microbiota composition and/or increased metabolic capacity for conversion of cysteine to $\mathrm{H}_{2} \mathrm{~S}$, and/or increased availability of cysteine as precursor for $\mathrm{H}_{2} \mathrm{~S}$ synthesis, the $\mathrm{H}_{2} \mathrm{~S}$ luminal content may increase. An increased $\mathrm{H}_{2} \mathrm{~S}$ luminal concentration may destabilize the mucous layer, and increase the $\mathrm{H}_{2} \mathrm{~S}$ concentration in colonocytes. In situation of decreased capacity of the colonocytes for $\mathrm{H}_{2} \mathrm{~S}$ disposal by the Sulfide oxidation Unit (SOU), the gaseous mediator intracellular concentration may increase, then reducing the mitochondrial ATP synthesis, a process that, together with an increased expression of the proinflammatory interleukin IL-6, and of the inducible form of Nitric Oxide Synthase (iNOS), likely participates in the inflammatory response in colonocytes. In contrast, complete inhibition of the tiny intracellular production of $\mathrm{H}_{2} \mathrm{~S}$ in colonocytes by the cystathionine beta-synthase (CBS) is counterproductive, as a minimal amount of $\mathrm{H}_{2} \mathrm{~S}$ is likely necessary to limit the risk of colonic mucosal inflammation, raising the view that $\mathrm{H}_{2} \mathrm{~S}$, depending on its intracellular concentration, is a double-edge sword for the intestinal epithelium.

Figure 4. Schematic representation of the effect of increased intracellular production of hydrogen sulfide on the development of late-adenoma colonic 
1018

1019

1020

1021

1022

1023

1024

1025

1026

1027

1028

1029

1030

1031

1032

1033

1034

1035

1036

1037

1038

1039

1040

1041

1042

1043

1044

epithelial cells. When cystathionine beta-synthase (CBS) activity is increased in late adenoma colonocytes, the endogenous production of $\mathrm{H}_{2} \mathrm{~S}$ from cysteine increases, thus stimulating mitochondrial oxygen consumption and thus ATP production. This increased ATP production from mitochondrial oxidative phosphorylation, together with increased glycolysis would favor the cell proliferative capacity.

Figure 5. Schematic representation of the effect of low luminal hydrogen sulfide concentration and increased endogenous production of $\mathrm{H}_{2} \mathrm{~S}$ in colonocytes originating from colorectal carcinoma. Low $\mathrm{H}_{2} \mathrm{~S}$ luminal concentration together with increased endogenous $\mathrm{H}_{2} \mathrm{~S}$ production through increased cystathionine beta-synthase (CBS) activity, are associated with $\mathrm{H}_{2} \mathrm{~S}$ oxidation by the sulfide oxidizing unit (SOU), and thus stimulation of mitochondrial oxygen consumption, and ATP production. When $\mathrm{H}_{2} \mathrm{~S}$ accumulates in cancerous cells, it modifies lactate deshydrogenase by $\mathrm{S}$ sulfhydration, thus enhancing its catalytic activity and thus glycolysis. This increased ATP production in the mitochondria, and increased glycolysis would favor the proliferative capacity of cancerous colonocytes.

Figure 6. Schematic representation of the effects of high luminal hydrogen sulfide concentration in colonocytes originating from colorectal carcinoma. High $\mathrm{H}_{2} \mathrm{~S}$ luminal concentration above the capacity of the sulfide oxidizing unit (SOU) for $\mathrm{H}_{2} \mathrm{~S}$ disposal, markedly reduces mitochondrial oxygen consumption, and thus ATP mitochondrial synthesis. Meanwhile, high $\mathrm{H}_{2} \mathrm{~S}$ concentration inhibits the cell proliferative capacity, and thus ATP utilization in the anabolic pathways associated with cell growth. This process, together with increased glycolysis, allow to maintain the ATP cell content, thus allowing the cancerous cells to maintain their viability. 


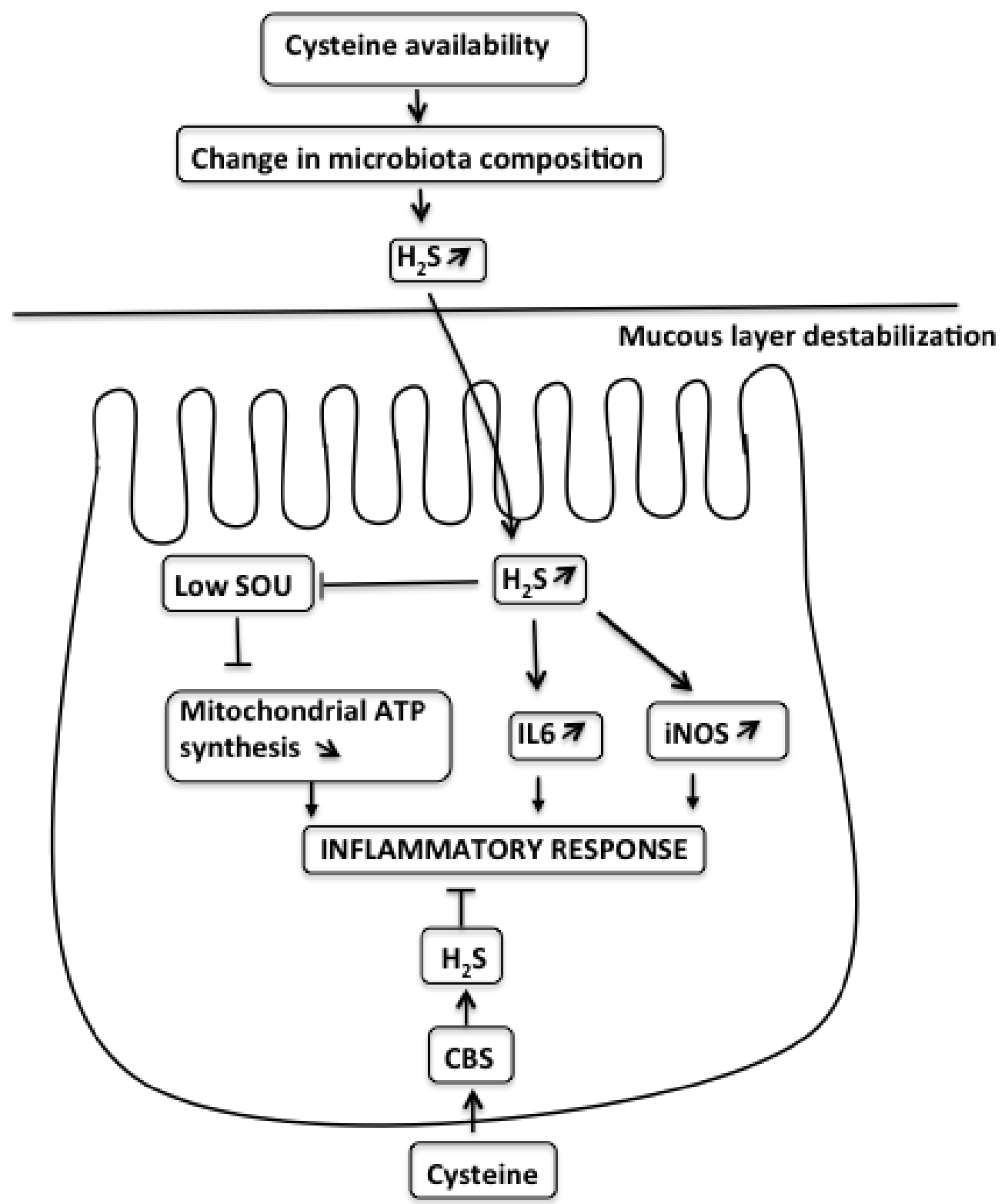




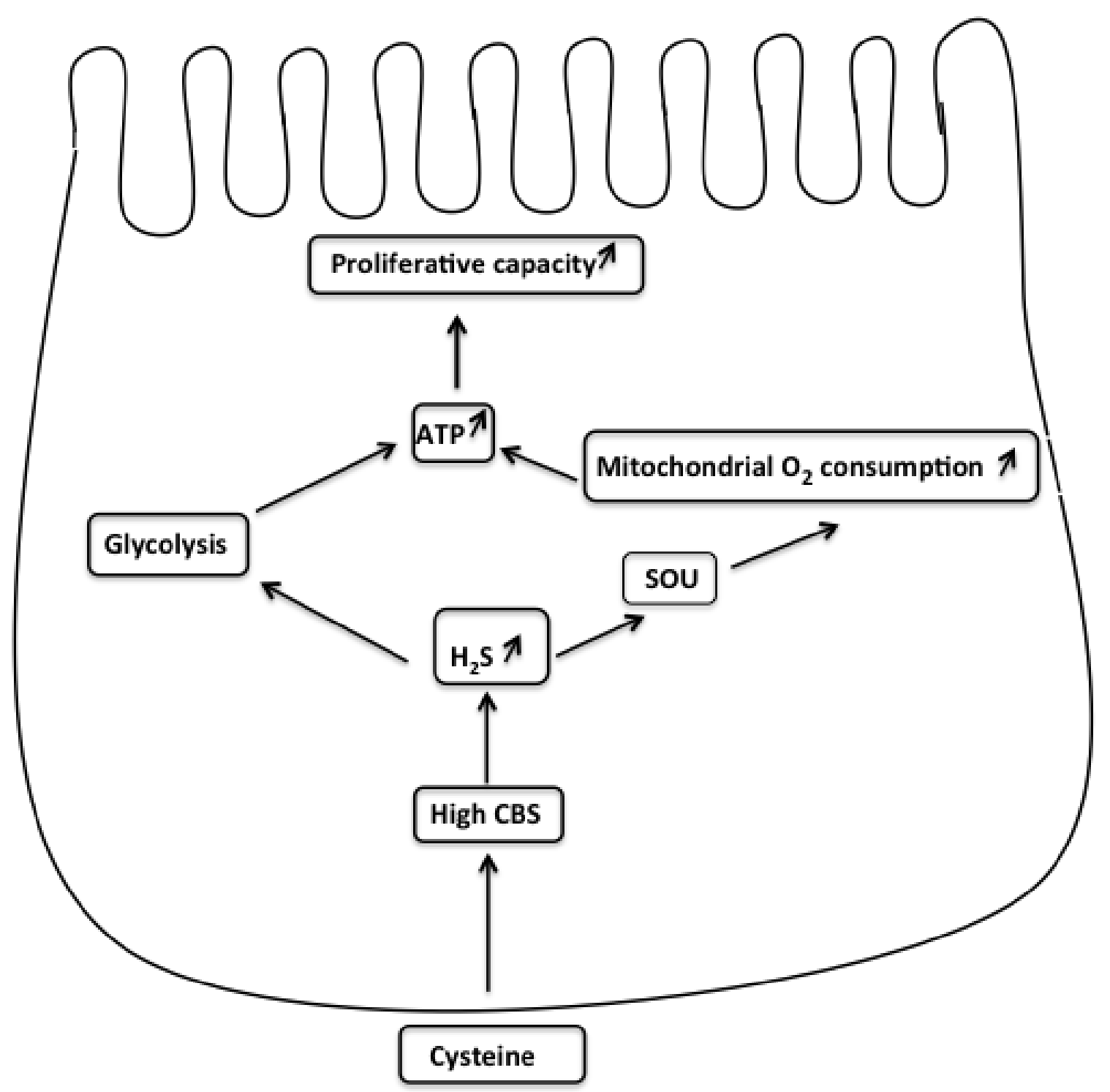




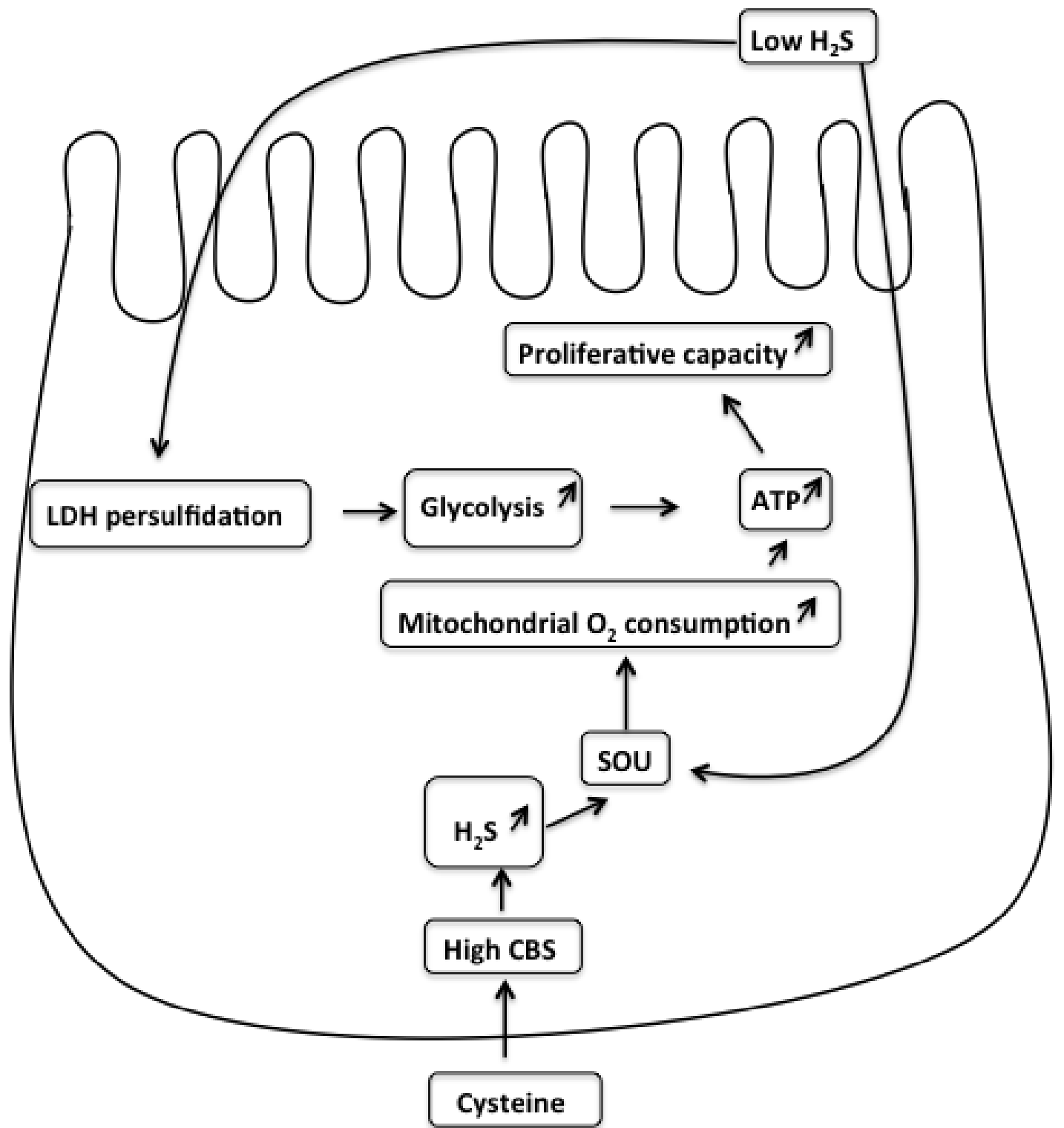




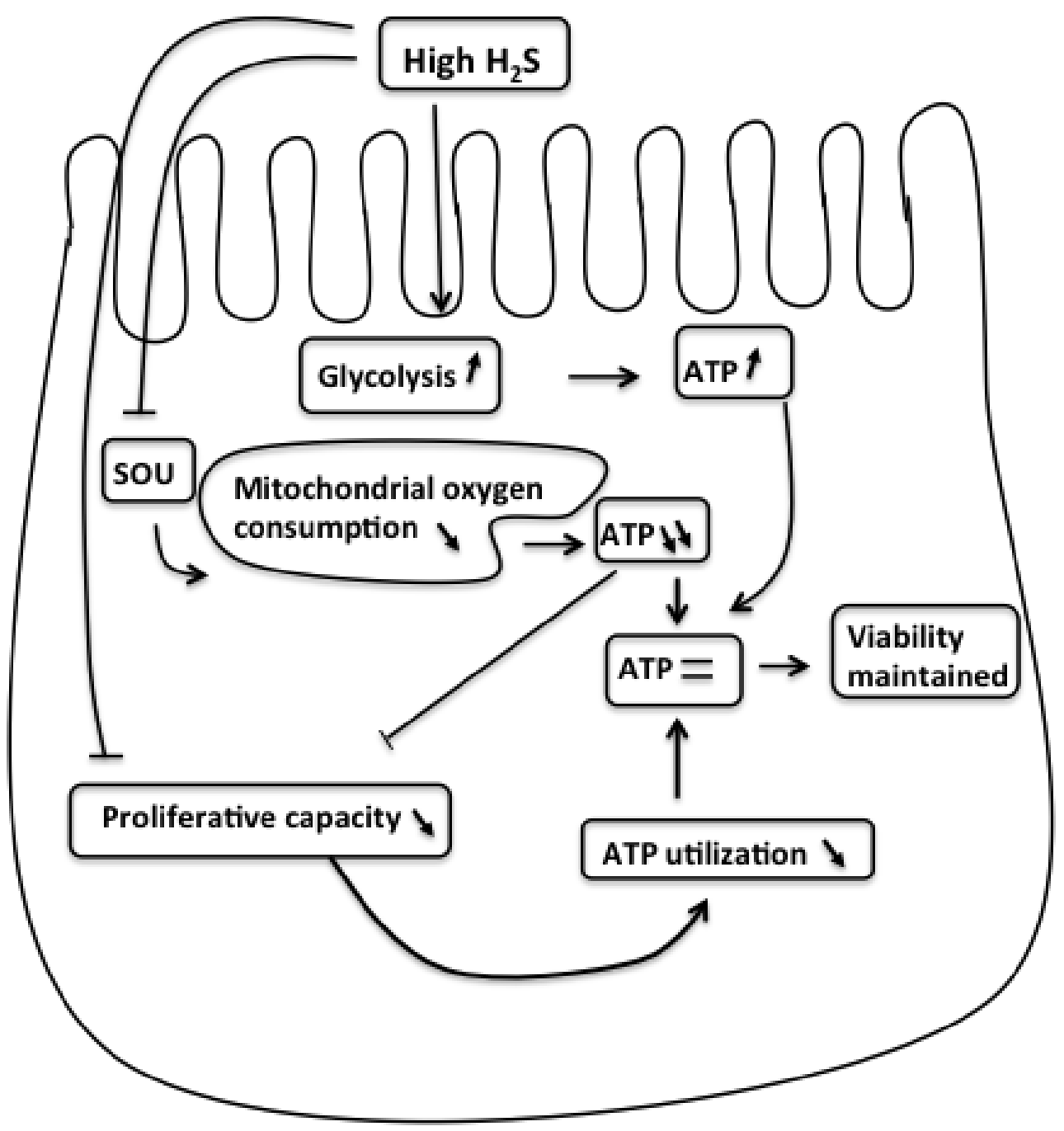


